The Society for Healthcare Epidemiology of America

\begin{tabular}{|c|c|c|c|}
\hline President & John M. Boyce, MD & Past President & Elias Abrutyn, MD \\
\hline President-Elect & Dale N. Gerding, MD & ACADEMIC COUNCILOR & Leonard Mermel, DO, SCM \\
\hline Vice President & William Jarvis, $\mathrm{MD}$ & ACADEMIC COUNCLLOR & Julie L. Gerberding, MD, MPH \\
\hline Treasurer & Loreen A. Herwaldt, MD & Practice Councilor & Donald R. Graham, MD \\
\hline SECRETARY & Larry J. Strausbaugh, MD & Practice Counchlor & Barbara Wade, MD \\
\hline
\end{tabular}

\section{SHEA CDC Guidelines}

The SHEA CDC guidelines are available now! Twelve guidelines, including the new HIV and HBV postexposure prophylaxis guidelines can be purchased by calling Etna Communications at 1-800-552-0076. A single volume is only $\$ 99$ for SHEA members.

\section{Biosafety}

The fourth edition of Biosafety in Microbiological and Biomedical Laboratories $(\mathrm{CDC} / \mathrm{NIH})$ is printed and on-line now. Check it out at: http://www.cdc.gov/od/ohs/ biosfty $/ \mathrm{bmbl4} / \mathrm{bmbl4toc.htm}$.

\section{Spotted the Site?}

'The ResistanceWeb (http:// resistanceweb.mfhs.edu) offers 10 years of drug-resistance tracking collected in over 200 North American hospitals since 1988, antibiotic-use data, and demographic information. After registration (free), users can search either for resistance patterns or antibiotic-use information, or one of these in relation to others. The Clinical

\section{Calendar}

Sep 6-9. Vaccines and Immunization Into the Next Millennium. Manchester, UK. Info: james. arthur@cmc.co.uk.

Sep 8-10. First International Congress on Cytokines/Chemokines in Infectious Diseases. Bethesda, MD. Info: meetings@imedex.com.

Sep 10-13. Second IFIC Conference, Controlling Infection in Healthcare. George, Western Cape, South Africa. Info: altagrc@ mweb.co.za.

Sep 26-29. 39th Interscience Conference on Antimicrobial Agents and Chemotherapy. San Francisco, CA. Info: meetingsinfo@asmusa.org.

Oct 14-16. Trends in Invasive Fungal Infections. Valetta, Malta. Info: tifi@concorde-uk.com.

Oct 16-19. SHEA/CDC course. Dallas, TX. Info: 609-4237222 , ext 350 .

Oct 18-21. APIC's Fall ICE I course. Savannah, GA. Info: http:// www.apic.org.

Oct 23-27. Fifth International Congress on AIDS in Asia and the Pacific. Kuala Lumpur, Malaysia. Info: http://www.icaap99.org.my.
Oct 27-30. International Meeting on Antimicrobial Chemotherapy in Clinical Practice. Genoa, Italy. Info: congress_studio@ multimedia.it.

Oct 29-Nov 2. European SHEA/ESGNI Training Course. Ooghduyne, The Netherlands. Info: a.voss@mmb.azn.nl.

Nov 2-6. Second World Congress of Pediatric Infectious Diseases. Manila, Philippines. Info: 1161170@compuserve.com.

Nov 10. APIC's software course. Ft Lauderdale, FL. Info: http://www.apic.org.

Nov 18-21. Infectious Diseases Society of America 37th Annual Meeting. Philadelphia, PA. Info: http://www.idsociety.org.

Dec 13-17. HIS/PHLS Course in Sterilisation, Disinfection and Hospital Hygiene. Falfield, Gloucestershire, UK. Info: bcook son@phls.nhs.uk.

Dec 16-17. International Conference on the Analysis and Interpretation of Disease Clusters and Ecological Studies. (followed on Dec 18 by a Bayesian software workshop). London, UK. Info: j.c.wakefield@ic.ac.uk.
Pharmacokinetics Laboratory at the Millard Fillmore Hospital in Buffalo, New York, developed this Internet tool. The databases used are the product of a global antimicrobial sus- ceptibility team headed by Ronald Jones and Charles Ballow. For more information visit the site, or contact Jerome Schentag (jschenta@mfhs. edu). 